International Journal of Linguistics, Literature and Translation

ISSN: 2617-0299 (Online); ISSN: 2708-0099 (Print)

DOI: $10.32996 / \mathrm{ijllt}$

Journal Homepage: www.al-kindipublisher.com/index.php/ijltt

\title{
Task-induced Involvement Load, Vocabulary learning and Reading Comprehension Among Iranian Intermediate English as a Foreign Language Learners
}

\author{
Seyedeh Mitra Khodaparast ${ }^{1} \square$ and Mohammad Hossein Keshmirshekan ${ }^{2}$ \\ ${ }^{1}$ MA Student of TEFL, Islamic Azad University of Yazd, Yazd, Iran \\ ${ }^{2}$ Ph.D. Candidate of Applied Linguistics, Department of Foreign Languages, Kharazmi University, Tehran, Iran
}

$\square$ Corresponding Author: Seyedeh Mitra Khodaparast, E-mail: Mitra.Khodaparast67@gmail.com

ARTICLE INFORMATION ABSTRACT

Received: 10 October 2021

Accepted: 19 November 2021

Published: 30 November 2021

DOI: $10.32996 /$ ijllt.2021.4.11.23

\section{KEYWORDS}

Involvement load hypothesis, Reading skill, Vocabulary knowledge
The importance of vocabulary in a second language is so self-axiomatic that it renders learning and teaching a must. The present study aimed to explore whether the manipulation of the task components, as proposed by Laufer and Hulstijn, affected the acquisition of English vocabularies by EFL learners. The present study followed an experimental design in that it used pre-test and post-test to collect data from the participants. The current research included $50 \mathrm{EFL}$ students from two private English language institutions in Yazd, Iran. The study included two distinct reading tasks that placed varying loads on participants. The two reading texts were controlled for their difficulty level: one with the high level of involvement load and the other with lack of involvement load, thus two experimental groups. There was a reading comprehension exam for those who participated in the first experimental group (with a high involvement load). Reading comprehension was assessed using the first Vocabulary Knowledge Scale (VKS1), which measures vocabulary knowledge. The second reading comprehension assignment was simultaneously presented to the second experimental group (the one with a low involvement load). After two weeks, they were administered VKS2, and their results were recorded. Analyzing the data was done by using independent t-tests. Exposure to high levels of involvement load has been shown to impact vocabulary development in English learners. This is despite respondents being able to recall more words from high-involvement vocabulary acquisitions than from low-involvement vocabulary acquisitions. Findings from this study may be used to construct practical tasks of reading with suitable degrees of difficulty for English language learners (EFL/ESL) teachers and vocabulary instructors.

\section{Introduction}

Learning vocabulary in a second language (L2) is an integral part of learning a new language. Linguists have a strong consensus (Laufer, 2001; Nation, 2001) that a single word serves as the fundamental building block of language acquisition. Although the optimal technique to acquire vocabulary is still a mystery, efforts have been undertaken to find strategies to improve learners' vocabulary. Laufer and Hulstijn's (2001) involvement load hypothesis (ILH) has been one of the most prominent theories.

There are three critical components to vocabulary acquisition and retention: need $(\mathrm{N})$, search $(\mathrm{S})$, and evaluation (E) (Lauer \& Hulstijn, 2001). A load of a task is the total of the significance levels of these three aspects, according to the theory. Because of this, activities with a greater level of involvement index are more successful in terms of vocabulary acquisition and retention than tasks with a lower level of involvement (Laufer \& Hulstijn, 2001).

The need to acquire and teach vocabulary in a second language is self-evident. According to linguist Wilkins (1997), "without grammar, little can be transmitted; without vocabulary, nothing can be communicated" (original italic). Words are the building blocks of all languages, and they give them life in the first place. Accordingly, the acquisition of already existing and yet-to-beborn vocabularies is a never-ending phenomenon in languages. Even in their native language, English learners are constantly

Copyright: (c) 2021 the Author(s). This article is an open access article distributed under the terms and conditions of the Creative Commons Attribution (CC-BY) 4.0 license (https://creativecommons.org/licenses/by/4.0/). Published by Al-Kindi Centre for Research and Development, London, United Kingdom. 
battling with the issue of coinage, acquisition, and learning all at the same time. (Thornbury, 2002; Namaziandost, Hosseini, \& Utomo, 2020).

When it comes to learning a second language, the stakes are elevated tenfold. Learners of a new language are confronted with many unknown lexemes and their many different meanings. Almost everyone studying a second language and their instructors are aware of how time-consuming it may be to learn a new language. When confronted with the task, they are anxious (Laufer \& Hulstijn, 2001). That's why the study on vocabulary learning isn't as extensive compared to other SLA difficulties (Nation, 2001; Namaziandost, Sawalmeh, \& Izadpanah Soltanabadi, 2020; Richards \& Renandya, 2002).

Recently, interest in topics related to vocabulary acquisition has revived again. Authored and edited books exclusively devoted to vocabulary indicate the revival of interest in L2 vocabulary (Thornbury, 2002; Namaziandost \& Imani, 2020; Farraniva AcmedIsmael, 2021; Latip-Panggaga, 2021). Much effort has been made to understand how L2 vocabulary can be acquired under different learning conditions and what factors influence the effectiveness and patterns of L2 vocabulary acquisition (Jiang, 2002; Shakibaei, Shahamat, \& Namaziandost, 2019). Concerning vocabulary, one of the recurrent themes in the realm of SLA has been the relationship between vocabulary knowledge and language proficiency, particularly in respect of reading. Specifically, the topic has been focused on the link between vocabulary development and accidental reading to narrow it down even more. Another widely held premise in vocabulary learning studies is that words are learned incidentally while reading, which is the basis for all subsequent vocabulary acquisition (Chen \& Truscott, 2010; Namaziandost, Neisi, \& Banari, 2019). Before furthering the discussion more, a definition of incidental learning is in order. According to research on both first and second language development, vocabulary acquisition happens spontaneously when students try to grasp new words they read or hear in a specific circumstance. "Incidental learning" refers to this kind of learning since it happens when students focus on something other than word acquisition (Paribakht \& Wesche, 1999; Ziafar \& Namaziandost, 2019).

\subsection{Research Questions}

This study aimed to address the following research questions:

1. Is there any significant relationship between levels of involvement load of different tasks of vocabulary?

2. Is there any difference between retention of vocabularies embedded in tasks of vocabularies and incidentally learned vocabularies?

\section{Literature Review}

\subsection{Involvement Load Hypothesis and Reading Skill}

In their research evaluation on the link between reading and vocabulary acquisition, Paribakht and Wesche conclude that "all of the studies indicate the importance of reading processes in vocabulary learning, but an unpredictable one, and not necessarily the most effective" (1997, p.175). They continue that unpredictability of what vocabularies are most likely acquired and to what extent that learning happens the scene hazier. Vocabulary development cannot be left to chance, and learners should not be encouraged to pick up new vocabularies for their pleasure. To compensate for the problems mentioned above, systematic improvement in vocabulary acquisition should be the student's goal. However, even though many studies have been conducted on incidental learning and vocabulary acquisition, no attempt has been made to put forward a theoretical framework for these studies, which would include describing how tasks used for unexpected learning can be manipulated to augment vocabulary acquisition and what the elements of those tasks are. Keating (2008) notices that one of the predominant obsessions of researchers and language instructors is recognizing tasks that are most likely to provide opportunities for the students to realize and expound on new words. He believes that this is one of the primary obsessions of researchers and language instructors.

Laufer and Hulstijn (2001) present a paradigm for task-induced engagement load based on findings in the literature. Laufer and Hulstijn (2001) contend with having recognized the elements of incidental tasks that they assume are beneficial to the detailed processing necessary for learning. They focus their assertion on an analysis of the tasks that have been used so far and conclusions drawn from the literature.

\subsection{Laufer and Hulstijn's Study (2001)}

Laufer and Hulstijn (2001) develop a new concept, Involvement, to stimulate conceptual and empirical study in L2 vocabulary. This concept is intended to promote theoretical and practical research in the domain of $\mathrm{L} 2$ vocabulary. They describe the concept as consisting of three motivational and cognitive aspects: the need for, the search for, and the assessment of the construct. In what follows, an attempt is made to throw light on the dimensions through theoretical definition and exemplification. According to their description, they describe the Need element as the "desire to conform with the work requirements, where job requirements may be either externally enforced or self-inflicted," according to their definition. (See p. 14). In addition to the concept, they categorize Need into two categories: "moderate" and "strong." The former indicates that the need is put on the learner from outside, i.e., that 
it is not pushed on the learner. In the case of the latter, the learner is the one who creates the requirement on their own. If, for example, a student is asked to construct a phrase using terminology that their instructor has established, the teacher forces the need externally, resulting in a moderate level of need (Shafiee, Mobini, Namaziandost, \& Ghodoosi, 2020).

If, on the other hand, the same student chooses to employ a vocabulary that he requires in his performance, then the Need is deemed to be self-imposed, which means that it is extreme. Laufer and Hulstijn (2001) argue that the need is significant in this case since it is something that the student has placed on him or herself. The motivating component of the concept of Involvement was developed from the discussion so far. The cognitive and affective components of the notion are the other two to be examined. The first of them is called Search. Search is defined as "the attempt to find the meaning of an unknown L2 word or trying to find the $\mathrm{L} 2$ word for expressing a concept (e.g., trying to find the $\mathrm{L} 2$ translation of an $\mathrm{L} 1$ word) by consulting a dictionary or another authority (e.g., a teacher) (2001, p. 14). Evaluation is the third component of the construct of Involvement. Laufer and Hulstijn (2001) define it as "a comparison of a given the word with other words, a specific meaning of a word with its other meanings, or combining the word with other words to assess whether a word (i.e., a form-meaning pair) does or does not fit its context" (2001, p.14). Involvement may be operationally defined using counseling activities with varying degrees of need, searching, and evaluating, and as a result, it can be subjected to empirical research. This is precisely what we are looking for in the current research. So, to test the assumptions, the present study starts with two research questions and the corresponding hypotheses.

\subsection{Previous Studies on Involvement Load Hypothesis}

As argued by Laufer and Hulstijn, word acquisition and retention in a second language are dependent on the involvement load (i.e., the amount of need, search, and assessment) imposed by a task. Keating (2008) demonstrated that this is true (2001). Seventynine beginning Spanish learners participated in one of three vocabulary learning tasks that differed in the amount of involvement (i.e., mental attempt) they required: reading comprehension (no effort), reading comprehension plus target word suppliance (moderate effort), and sentence writing (high effort) (strong attempt). Following the expectations of the Involvement Load Hypothesis, the most extraordinary levels of retention were found in the sentence writing task, followed by lower levels in the reading plus fill-in task, and the lowest levels were found in the reading comprehension task When the amount of time spent on a job is taken into consideration, the reward associated with more time-consuming activities diminishes (Namaziandost, Razmi, Tilwani, \& Pourhosein Gilakjani, 2021).

In the same line of inquiry, Yaqubi, Rayati, and Allemzade Gorgi (2010) claimed that even though it is comprehensive, the 'involvement load hypothesis' in second language literature has not yet supplied a definitive solution to the question of vocabulary acquisition. Their research looked at task-induced engagement, which was initially proposed by Laufer and Hulstijn (2001) and tested in various task types. Seventy high proficiency EFL learners from two different English institutes in Isfahan, Iran, were randomly assigned to two experimental groups: gap-filling task fulfillment or reading comprehension task execution, to successfully scrutinize the involvement hypothesis in incidental learning. The Nelson Proficiency Test was used to assess the students' learning' proficiency in English.

Walsh (2009) and Namaziandost et al. (2021) presented quantitative studies comparing task features in terms of variables related to incidental vocabulary acquisition in English as a foreign language. The concept of Task-Induced Involvement developed by Laufer and Hulstijn (2001a) is used in this experiment. The participants were 223 high school students from two separate high schools in the area in their tenth grade. From the beginning, it was discovered that the two groups had very different levels of L2 vocabulary knowledge. Both moderate and vigorous assessment tasks were used in the study, and the results were compared between the two circumstances. In both groups, the activity requiring the creation of a "strong assessment" (original sentences) was shown to be more successful in enabling retention one week after the work was completed than the assignment requiring the creation of a "moderate evaluation" (gap fill). The "strong assessment" assignment, in addition, seemed to be more beneficial to the population with a greater baseline level of vocabulary knowledge, according to the results. For high school students in Japan, learner-initiated writing, including L2 terms unfamiliar to the learner proven to be an effective method of learning new language skills. Finally, he proposed a task-based learning strategy focused on a particular subject to enable this output by generating context for the learners.

To highlight the utility of dual-process models in describing the mechanism of credibility inference, Reinhard and Sporer (2008) selected three experiments. According to dual-process models ' assumptions, only high levels of task engagement and cognitive capability lead to intense verbal and nonverbal information processing when forming credibility judgments. Under conditions of low work engagement and mental ability, people tend to rely heavily on nonverbal cues when assessing the credibility of sources. Participants in Experiment 1 saw a video in which a source's nonverbal behavior (fidgety vs. calm) and verbal information (low vs. high credibility) were changed under low and high task participation. It was projected that participants' trustworthiness attributions were only impacted by their nonverbal conduct when minimal task participation. Verbal information was also utilized by 
participants who had a high level of task participation. In Experiments 2 and 3, the individuals' cognitive ability was changed. According to their findings, individuals with higher mental capacities utilized linguistic information to assess the trustworthiness of others, but those with lower cognitive capabilities did not.

It was shown that task difficulty and assistance might be tailored to the learner's competency level and perceived task load, either by an external agent, the learner herself, or both, according to research by Corbalan et al. (2008). Participants $(N=55)$ in a twoby-two factorial design research were able to influence the factor's adaptation (present or missing) as well as the task-selection process (program control or shared control). An adaptation-based learning strategy resulted in better results and less effort spent on the tasks, they determined. Higher learning outcomes and tremendous effort engaged in learning resulted from shared control over task selection. Adaptation also led to a higher level of task participation, according to their research.

Laufer (2001) investigated a few studies that found relatively minor improvements in L2 vocabulary from reading short and extended texts. Reading with word-focused assignments, on the other hand, produced superior outcomes. On the other hand, reading is more beneficial than a word-focused activity alone in L2 vocabulary development. According to the author, it is possible to explain and forecast task effectiveness using the concept of "task-induced participation load."

According to Laufer and Hulstijn, word acquisition and retention in a second language depend on the degree of need, search, and assessment that a task imposes. Keyvanfar and Badraghi (2011) explored this claim (2001). Pre-intermediate male and female Iranian EFL students were chosen for this project based on their scores on the Cambridge reading exam. As a result, students were assigned to do one of the three activities that differed in the level of participation they induced. Reading, reading with fill-in target words, and composing sentences were all part of the curriculum. After completing the exercises, students were evaluated on their knowledge and memory of the 14 unfamiliar target words two weeks later. According to their research findings, students profit more from sentence construction that necessitates comparing new words with those they already know. They concluded that the assessment component might be the most crucial factor in task-induced participation.

To support the Involvement Load Hypothesis in L2 vocabulary learning, Kim (2008) conducted two studies. Study 1 was a study of how task-induced engagement affects the initial acquisition and retention of target words by L2 learners. Posttest findings indicated that the composition group (involvement load index=3) scored higher than the reading and gap-filling groups. In other terms, the gap-fill group didn't outperform the reading group much. The delayed post-test, on the other hand, revealed substantial differences across the three groups. In his second experiment, Kim (2008) investigated whether the initial acquisition and retention of target words were affected similarly by two tasks that claimed to have the same amount of task-induced involvement (involvement index=3). Both assignments were equally helpful in helping students learn and retain new words, according to his findings.

\section{Methodology}

\subsection{Design of the Study}

The present study follows an experimental design in that it uses pre-test and post-test to collect data from the participants. Members of the experimental groups are given two types of treatment, and results are compared. The dependent variable is the operational definition of vocabulary knowledge, i.e., improving the participant's knowledge of the selected words exposed to them. The independent variable was the level of 'involvement load,' and the mediating variable was reading comprehension.

\subsection{Participants}

Participants of the present study were fifty learners at two private English language institutes in Yazd, Iran. The average number of students in each class fell between 20 to 30. Twenty were chosen from each category which was then allocated to each of the experimental groups. Their ages also ranged between 18 and 28 . They were both male and female, though gender was not the focus of this study.

\subsection{Instruments}

\subsubsection{Target vocabularies}

A total amount of 30 vocabularies were examined in the research. The criteria based on which the vocabulary was picked was their frequency; specifically, the target vocabularies should have a low frequency. That has been agreed upon carefully to ensure that participants have not been exposed to the vocabulary previously. So, these vocabularies were picked based on Nation's categorization (2001) of vocabularies. Also, to account for the inherent difficulty (the syllables can affect learning the vocabularies), all the target vocabularies were picked with the same number of syllables. The study's participants were asked to use only words with two syllables. Moreover, to reflect the extent of vocabularies, nouns, verbs, and adjectives were given an equal proportion of three out of nine. The current investigation did not focus on practical terms. 


\subsubsection{Instrument: Vocabulary Knowledge Scale (VKS)}

The (VKS) was created due to a university-based study on vocabulary growth among ESL students (Paribakht \& Wesche, 1997, 1999). This instrument captures various phases in the beginning development of core knowledge of provided words in a somewhat effective method. According to Paribakht and Wesche (1999), the VKS could be considered a valuable tool for researching how people first recognize and utilize new words. Self-perceived and proven knowledge of certain words in written form are assessed using the VKS instrument, which employs a scale that incorporates self-reports and performance tasks. The grades range from total unfamiliarity to awareness of the term and some notion of its meaning to the ability to employ the word with grammatical and semantic precision in a sentence. With the VKS, we wanted to capture early stages of word acquisition that can be accurately self-reported or efficiently demonstrated and that is exact enough to show increases over a short teaching time.

\subsection{Data collection Procedures}

The overall process of the investigation centered around two phases. In the first step, members of the first group were given the target terms and the VKS to confirm that they did not know the vocabulary. Those acquainted with vocabulary were excluded from the research. Then, individuals (E1) were obliged to sit for the first reading comprehension exam. Immediately, when they were finished up, VKS1 was utilized to assess if any learning had transpired in the target vocabulary. Simultaneously, the second experimental group (E2) was given another site's second reading comprehension test. After passing the test, students were given the VKS1 to verify the vocabulary learning in the target vocabularies, if any, due to the therapy. At this time, we had the early outcomes of the treatment. But, since we sought to test vocabulary retention after the immediate and incidental, use is made of the VKS2 after two weeks. This time, the two experimental groups (E1 \& E2) did not sit for reading comprehension exams. They were only provided the list of words they were exposed to two weeks ago during the reading comprehension assignments. The VKS2 had a series of questions that they were required to respond to.

\section{Results}

The study's initial research question was: Is there a significant link between degrees of involvement burden of various vocabulary tasks? Before the treatment, both groups were given similar reading passages, and then the VKS was given. VKS 1 was administered to participants immediately following the reading tests. The results are in the tables below.

Table 1: Students' Performance on VKS 1 (After reading)

\begin{tabular}{llllll}
\hline & Groups & N & Mean & Std. Deviation & Std. Error Mean \\
\hline \multirow{2}{*}{ Posttest } & HIL & 25 & 14.8800 & .92736 & .18547 \\
\cline { 2 - 5 } & LIL & 25 & 11.6400 & 1.60416 & .32083 \\
\hline
\end{tabular}

Note. HIL: High level of involvement load; LIL: Lack of involvement load

It is clear that the mean acquired from students with a high level of involvement load is more significant than that obtained from students with a low level of involvement load. The t-test was used to see whether there was a substantial difference in the performance of these two groups, and the findings are shown in table 2.

Table 2: Independent Samples Test on VKS 1

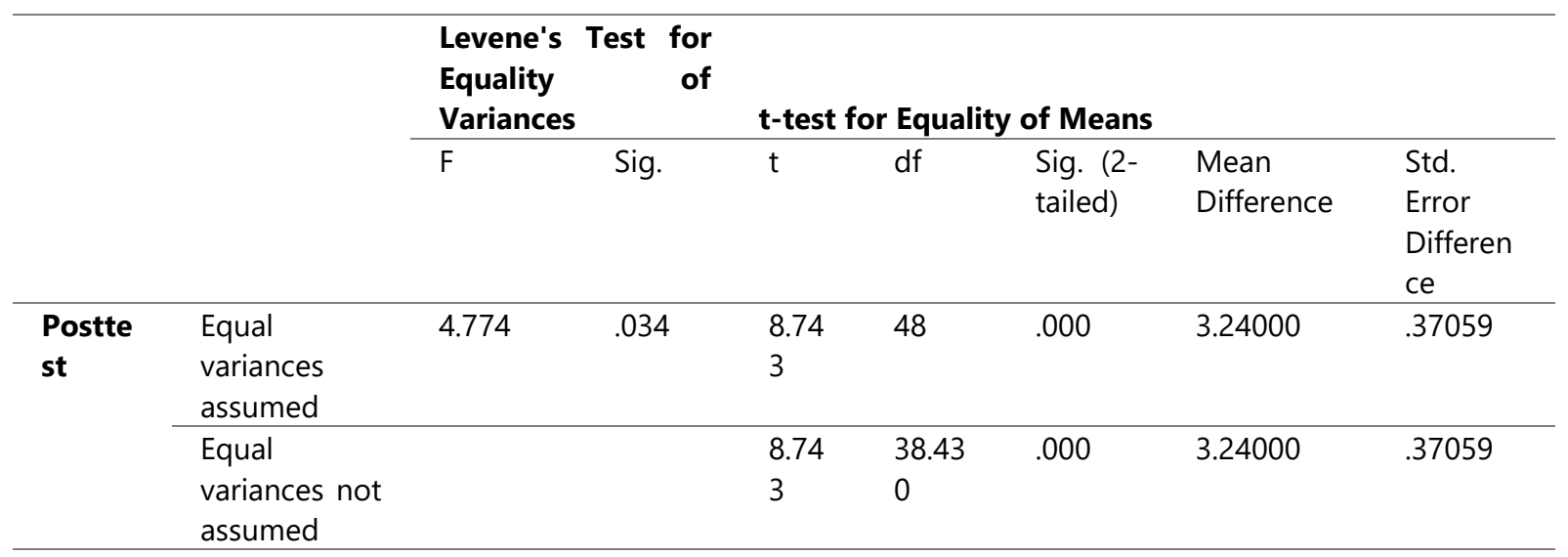


Table 2 shows that the Sig. value is 0.000 (Sig. 0.05), and that there is a substantial difference in the performances of the two groups. In other words, the group with a high degree of involvement load performed much better than the group with a low level of involvement load. This distinction is also shown in the following Figure.

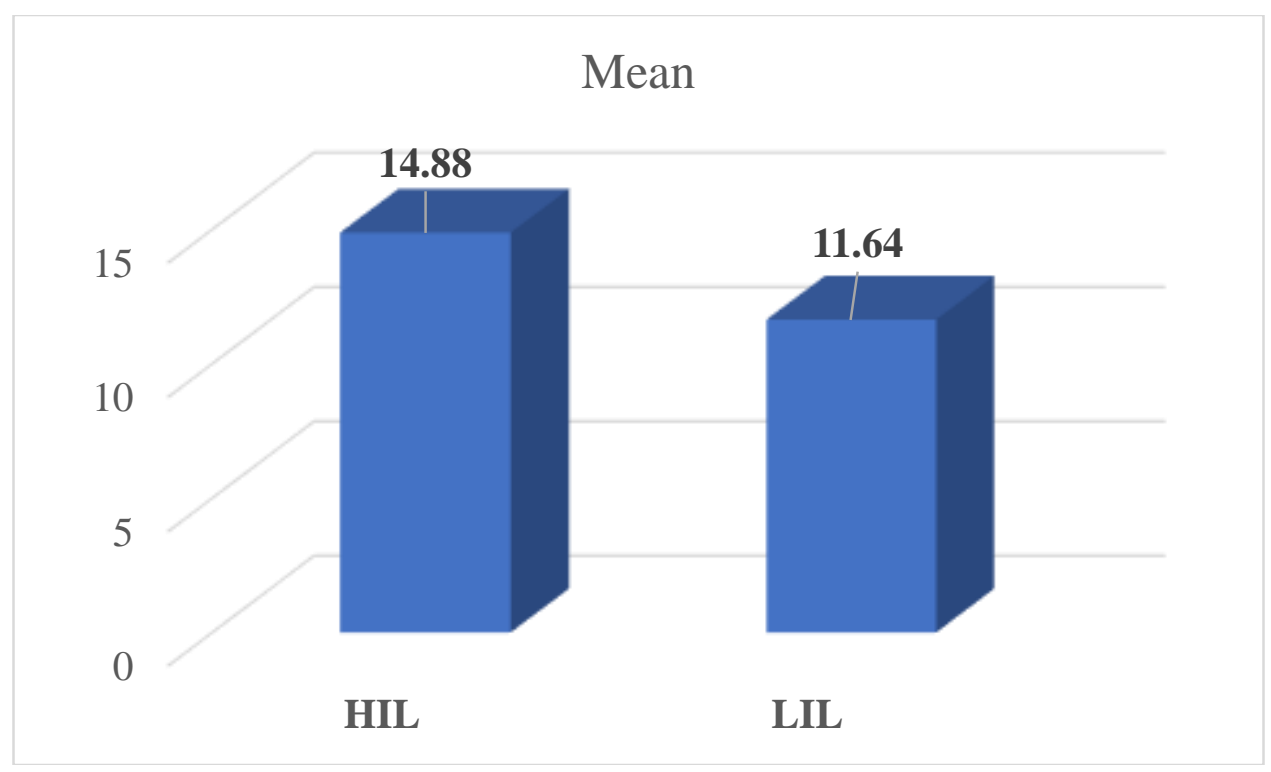

Figure 1. Comparison of Groups' Performances on VKS 1

The 2 nd question in this research was 'is there any difference between the retention of vocabularies embedded in tasks of vocabularies and the incidentally learned vocabularies?' To produce a response, the same approaches as for the first research question were used.

Table 3: Students' Performance on VKS 2 (retention)

\begin{tabular}{llllll}
\hline & Groups & N & Mean & Std. Deviation & Std. Error Mean \\
\hline \multirow{2}{*}{ Retention } & HIL & 25 & 13.4800 & 3.01552 & .60310 \\
\cline { 2 - 5 } & LIL & 25 & 12.2400 & 1.80924 & .36185 \\
\hline
\end{tabular}

The mean for the group with a high degree of involvement is 13.4800 , while it is 12.2400 for the group with no involvement. Notable is the abrupt decline in the group's performance with a high degree of involvement burden, from 14.8800 in VKS 1 to 13.4800 in VKS 2. However, in the group without involvement burden, the mean rose marginally from 11.6400 to 12.2400 , indicating that retention had no impact on exposure to involvement load.

To determine any significant differences in the groups' performance on VKS2 (retention), an independent samples t-test was performed on the scores obtained after the gap.

Table 4: Independent Samples T-test on VKS 2

\begin{tabular}{|c|c|c|c|c|c|c|c|c|}
\hline & & \multirow{2}{*}{$\begin{array}{l}\text { Levene's } \\
\text { Equality } \\
\text { Variances } \\
\text { F }\end{array}$} & $\begin{array}{r}\text { Test fo } \\
0\end{array}$ & \multicolumn{3}{|c|}{ t-test for Equality of Means } & \multirow[b]{2}{*}{$\begin{array}{l}\text { Mean } \\
\text { Difference }\end{array}$} & \multirow[b]{2}{*}{$\begin{array}{l}\text { Std. } \\
\text { Error } \\
\text { Differen } \\
\text { ce }\end{array}$} \\
\hline & & & Sig. & $\mathrm{t}$ & $d f$ & $\begin{array}{l}\text { Sig. (2- } \\
\text { tailed) }\end{array}$ & & \\
\hline \multirow[t]{2}{*}{$\begin{array}{l}\text { Posttes } \\
\mathrm{t}\end{array}$} & $\begin{array}{l}\text { Equal } \\
\text { variances } \\
\text { assumed }\end{array}$ & 17.482 & .000 & $\begin{array}{l}1.76 \\
3\end{array}$ & 48 & .084 & 1.24000 & .70333 \\
\hline & $\begin{array}{l}\text { Equal } \\
\text { variances not } \\
\text { assumed }\end{array}$ & & & $\begin{array}{l}1.76 \\
3\end{array}$ & $\begin{array}{l}39.29 \\
6\end{array}$ & .086 & 1.24000 & .70333 \\
\hline
\end{tabular}


As observed in Table 4, the independent samples t-test revealed that the difference between mean scores obtained from the two groups was not significant in the VKS2. In other words, following separation from the reading passage, the group with a high degree of involvement load also proved to have a high mean score on VKS. However, the group with a lack of involvement burden exhibited no substantial variation between VKS 1 and VKS 2.

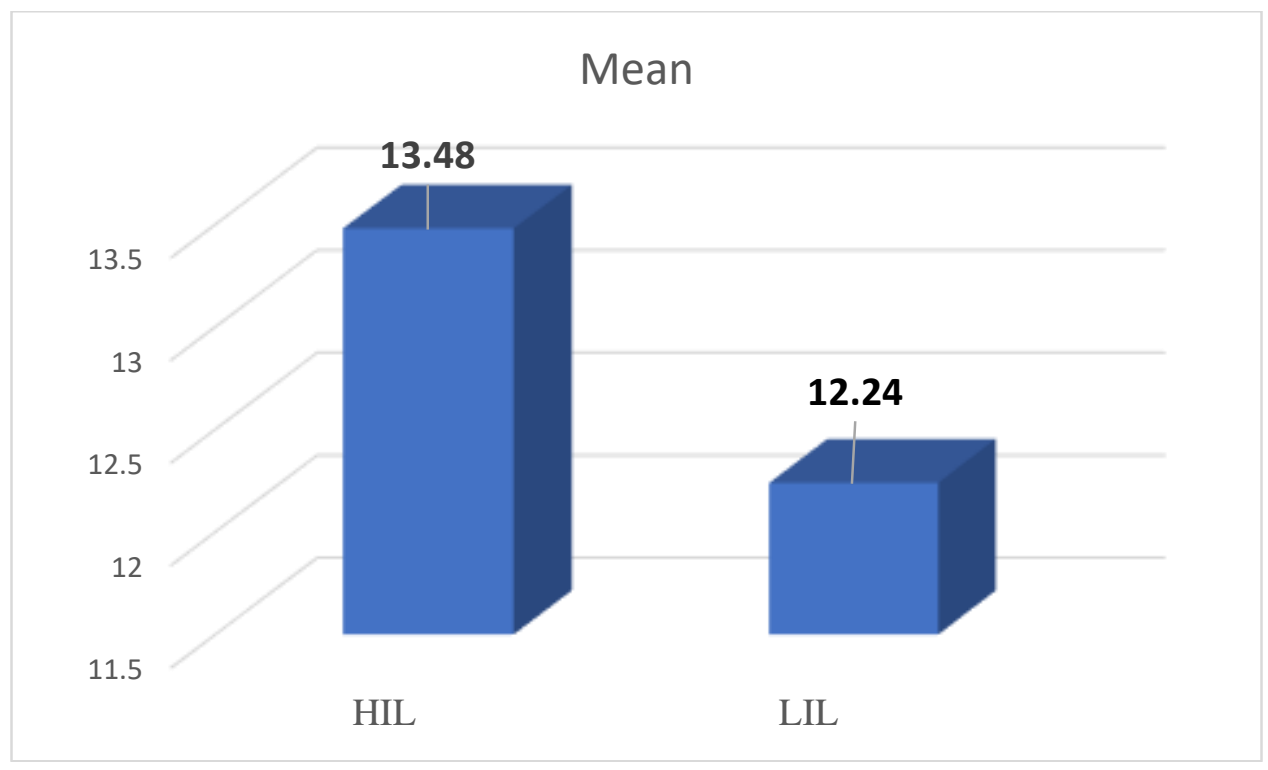

Figure 2. Comparison of Groups' Performances on VKS 2 (Retention)

In the preceding Figure, it is also indicated that the group with a high degree of involvement burden reduced its performance on the VKS test after the retention. However, the chart suggests that this group is one level higher than the group with no degree of involvement burden; this difference is smaller than one in reality. All in all, from this figure, it can be claimed that mean scores of both groups reached about similar values in the retention test; however, the one with a high degree of involvement load was somewhat higher.

\section{Discussion and Conclusion}

The findings of the current research accord with those of some studies in the literature. Some past investigations revealed that more significant degrees of involvement loads did generate superior acquisition levels on the part of the learners. The current research found that increased involvement load led to better vocabulary learning in reading tasks; thus, it follows the literature's line of inquiry. Findings obtained by Keating (2008), Walsh (2009), Reinhard and Sporer (2008), Corbalan et al. (2008), and Keyvanfar and Badraghi (2011) were in accord with those found by the current research. The same as the outcomes acquired by the recent investigation, they also concluded that involvement load might play a critical role in delivering improved language learning. Equally, all these researches combined with the current one suggest that precise manipulation of this involvement load is vital and demands the most incredible attention to the target students, degree of task complexity, classroom setting, level of competence, etc.

More precisely, Keating (2008) revealed that vocabulary acquisition and retention in a second language are dependants upon a task's involvement load (i.e., the amount of demand, search, and assessment it imposes), as described by Laufer \& Hulstijn (2001). (2001). In a similar line, Yaqubi et al. (2010) recognized the advantages of employing high involvement load activities by stating that instructors and language learners may utilize tasks with higher involvement indexes regardless of their kind to increase their vocabulary acquisition. Moreover, Reinhard and Sporer (2008) added credence to the current conclusion by asserting that individuals with high cognitive capability employed verbal information for their credibility attribution. Similarly, Corbalan et al. (2008) supported one kind of task by maintaining that shared power over task selection led to better task involvement. To put it another way, they encouraged students to put in more effort while studying to get better learning results.

The experimental findings were similar to those reported by Keyvanfar and Badraghi (2011). (2011). They also corrected the analysis of tasks for the integration of vocabulary and proposed that the evaluation component may be playing a critical function in taskinduced involvement burden. Finally, Lu and Huang (2009), who evaluated three kinds of tasks, concluded that the one with a more significant involvement load provided superior vocabulary retention compared to other types. 
On the other hand, a lot of research came to opposing conclusions suggesting that degrees of involvement load did not generate various levels of vocabulary learning. Such results were achieved by Yaqubi et al. (2010). (2010). For them, the 'involvement load hypothesis' has not yet supplied a concrete response to vocabulary acquisition despite its inclusivity. However, these findings are in keeping with the second phase of the current investigation in that results were not significant after the retention.

The purpose of the current research was to determine whether the alteration of task components, as suggested by Laufer and Hulstijn (2001), influenced English vocabulary learning in reading tasks. According to the findings of this research, students' English vocabulary may benefit significantly by being exposed to high levels of involvement load. Another purpose followed in this research was to assess the impact of task involvement after a time gap. In other words, retention of the vocabulary was to be examined for reading tasks with a lack of and high degrees of involvement burdens. There was no statistically significant difference in retention between vocabulary learned with a high involvement load and vocabulary learned with no involvement load. Participants' recall of vocabulary realized via increased levels of involvement was superior to that of vocabulary learned through low levels of involvement, as shown by this study.

All in all, it can be claimed that the results of the current research were two-fold. Firstly, good and substantial benefits of implementation of reading activities were authorized for improved learning of vocabulary. Better outcomes were achieved when the participants were more interested in the vocabulary inside the reading tasks. Secondly, it became clear that the same positive and substantial effects of more significant involvement-load tasks were not present in the delayed posttest. Nonetheless, while these findings were not compelling, it was observed that group members with a more considerable involvement load exhibited superior performance on the delayed posttest than those of the group with a lack of involvement load exposed to them.

Regarding the role of vocabulary in EFL/ESL situations, including vocabularies with suitable degrees of difficulty is an important topic. So much care has to be devoted to selecting relevant words for the EFL/ESL learners. In this light, such signs may be better appreciated when referring to Wilkin, who considered that very little can be expressed; without vocabulary, nothing can be conveyed. Regarding the present results, it can be argued that developing activities with high involvement loads might provide new techniques and solutions to existing difficulties within language learning. Findings may be applied by EFL teachers, instructors, and vocabulary trainers in helping them construct tasks of reading with acceptable degrees of difficulty using vocabularies with sufficient involvement load level. They may verify vocabulary to be integrated into the reading activities for their degrees of involvement burden and then provide them to the participants. In this manner, they may teach learners with higher vocabulary knowledge.

This research may also be used to develop high-involvement exercises for EFL textbook authors to implement. These may be added with reading exercises to make reading a more involved and attractive activity. Furthermore, they may be able to use vocabulary with a high involvement load for purposes other than reading. For instance, practitioners of listening, writing, and speaking skills might give their pupils projects whose vocabulary involvement loads would be more prominent. As a result, students will be able to more quickly and effectively learn the vocabulary that is essential to every piece of $L 2$ content.

Further research may study various degrees of vocabulary involvement loads and assess them for their impact on each of the other three language abilities than reading. Moreover, the same reading tasks as those provided by the current research may be explored by future studies for MA students of English, BA, MA students of English, or more broadly BA and MA students of other areas in ESP courses, and EFL/ESL learners of varying levels of competence. This might result in intriguing discoveries which would be advantageous to enhance vocabulary teaching and learning.

Since the current research mainly dealt with two degrees of involvement loads, namely high level and absence of involvement load, future studies may take care of a more significant number of involvement loads. In this manner, a variety of tasks with varying degrees of involvement burdens may be studied. Results would be valuable to practitioners of vocabulary, and they would have a large selection of exercises to employ for a particular set of learners. This might result in novel approaches to teaching language and could make English learning a more engaging activity. The last proposal for additional study might be the delivery of various delayed posttests with varying time intervals. The current research examined delayed posttests after a single period. Future research may take care of posttest with varied time intervals to evaluate which period would serve as the best for the retention of vocabulary with high involvement loads.

Funding: This research received no external funding.

Conflicts of Interest: The authors declare no conflict of interest.

ORCID iD

Mohammad Hossein Keshmirshekan: 0000-0001-9040-3046 


\section{References}

[1] Chen, C., \& Truscott, J. (2010). The effects of repetition and L1 lexicalization on incidental vocabulary acquisition. Applied Linguistics, 31(5), 693-713.

[2] Corbalan, G., Kester, L., \& Van Merriënboer, J. J. (2008). Selecting learning tasks: Effects of adaptation and shared control on learning efficiency and task involvement. Contemporary Educational Psychology, 33(4), 733-756.

[3] Farraniva A. (2021). Metacognitive learning strategies: their effects on the reading comprehension performance of grade five pupils. International Journal of Linguistics, Literature, and Translation, 4(5), 107-117. https://doi.org/10.32996/ijllt.2021.4.5.10.

[4] Jiang, N. (2002). Form-meaning mapping in vocabulary acquisition in a second language. Studies in Second Language Acquisition, 24(04), 617-637.

[5] Keating, G. D. (2008). Task effectiveness and word learning in a second language: The involvement load hypothesis on trial. Language Teaching Research, 12(3), 365-386.

[6] Keyvanfar, A., \& Badraghi, A. H. (2011). Revisiting Task-Induced Involvement Load and Vocabulary Enhancement: Insights from the EFL Setting of Iran. Man \& the Word/Zmogus ir zodis, 13(3).

[7] Latip-Panggaga, S. (2021). Cooperative learning strategy: its effects on enhancing the vocabulary and reading compression skills of MSU-ILS grade six pupils. International Journal of Linguistics, Literature, and Translation, 4(4), 55-69. https://doi.org/10.32996/ijllt.2021.4.4.7.

[8] Laufer, B. (2001). Reading, word-focused activities, and incidental vocabulary acquisition in a second language.

[9] Laufer, B., \& Hulstijn, J. (2001). Incidental vocabulary acquisition in a second language: The construct of task-induced involvement. Applied linguistics, 22(1), 1-26.

[10] Lu, J., \& Huang, J. (2009). An empirical study of the involvement load hypothesis in incidental vocabulary acquisition in EFL listening.

[11] Namaziandost, E., \& Imani, A. (2020). Compensatory strategies and Iranian intermediate EFL learners' speaking fluency: focusing on selfrepetition and comprehension check strategies. International Journal of Linguistics, Literature, and Translation, 3(3), 107-114. Retrieved from https://al-kindipublisher.com/index.php/ijllt/article/view/1111.

[12] Namaziandost, E., Hosseini, E., Utomo, D.W. (2020). A comparative effect of high involvement load versus lack of involvement load on vocabulary learning among Iranian sophomore EFL learners. Cogent Arts and Humanities, 7(1). https://doi.org/10.1080/23311983.2020.1715525.

[13] Namaziandost, E., Neisi, M., \& Banari, R. (2019). The impact of code-switching on vocabulary learning among Iranian upper-intermediate EFL learners. International Journal of Linguistics, Literature, and Translation (IJLLT), 2(5), 309-318.

[14] Namaziandost, E., Razmi, M. H., Tilwani, S. A., \& Pourhosein Gilakjani, A. (2021). The impact of authentic materials on reading comprehension, motivation, and anxiety among Iranian male EFL learners. Reading \& Writing Quarterly, DOI: 10.1080/10573569.2021.1892001.

[15] Namaziandost, E., Sawalmeh, M. H. M., \& Izadpanah Soltanabadi, M. (2020). The effects of spaced versus massed distribution instruction on EFL learners' vocabulary recall and retention. Cogent Education, 7(1). DOI: 10.1080/2331186X.2020.1792261

[16] Namaziandost, E., Sawalmeh, M.H.M., Tilwani, .SA., Ziafar, M., Arianti, A., Hernández, R. M., Razzhivin, O.M., Ocaña-Fernández, Y., FusterGuillén, D., \& Palacios Garay, J. (2021). Manipulation of the Involvement Load of L2 Reading Tasks: A Useful Heuristic for Enhanced L2 Vocabulary Development. SAGE Open. doi:10.1177/21582440211051723

[17] Nation, I. S. P. (2001). Learning vocabulary in another language. Cambridge: Cambridge University Press

[18] Paribakht, T. S., \& Wesche, M. (1997). Vocabulary enhancement activities and reading for meaning in second language vocabulary acquisition. Second language vocabulary acquisition: A rationale for pedagogy, 55(4), 174-200.

[19] Paribakht, T. S., \& Wesche, M. (1999). Reading and "incidental" L2 vocabulary acquisition. Studies in second language acquisition, 21(02), 195-224.

[20] Reinhard, M. A., \& Sporer, S. L. (2008). Verbal and nonverbal behavior as a basis for credibility attribution: The impact of task involvement and cognitive capacity. Journal of Experimental Social Psychology, 44(3), 477-488.

[21] Richards, J. C., \& Renandya, W. A. (2002). Current research and practice in teaching vocabulary. Methodology in language teaching, $254-266$.

[22] Shafiee, S., Mobini, M., Namaziandost, E., \& Ghodoosi, S. (2020). Contribution of multiple intelligences to I2 writing of EFL learners. International Journal of Linguistics, Literature, and Translation, 3(6), 59-69. https://doi.org/10.32996/ijllt.2020.3.6.7

[23] Shakibaei, G., Shahamat, F., \& Namaziandost, E. (2019). The effect of using authentic texts on Iranian EFL learners' incidental vocabulary learning: The case of English newspaper. International Journal of Linguistics, Literature, and Translation (IJLLT), 2(5), 422-432

[24] Thornbury, S. (2002). How words are learned. How to teach vocabulary, 13-31.

[25] Walsh, B. A. (2009). Novel word learning of preschoolers enrolled in Head Start regular and bilingual classrooms: Impact of adult vocabulary noneliciting questions during shared storybook reading. Texas Woman's University.

[26] Wilkins, D. (1972). Linguistics in language teaching. Cambridge: CPU

[27] Yaqubi, B., Rayati, R. A., \& Allemzade Gorgi, N. (2012). The involvement load hypothesis and vocabulary learning: The effect of task types and involvement index on L2 vocabulary acquisition. Journal of Teaching Language Skills, 29(1), 145-163.

[28] Ziafar M., \& Namaziandost, E. (2019). Linguistics, SLA, and lexicon as the unit of language. International Journal of Linguistics, Literature, and Translation (IJLLT), 2(5), 245-250. 